Acta vet. scand. 1987, 28, 241-248.

From the Department of Microbiology and Epizootology,

College of Veterinary Medicine, Helsinki, Finland.

\title{
Transmission of Mycoplasma Dispar among Calves Collected and Reared for Beef Production
}

\author{
By R. Tanskanen
}

\begin{abstract}
Tanskanen R: Transmission of Mycoplasma dispar among calves collected and reared for beef production. Acta vet. scand. 1987, 28, 241-248. - Fortytwo calves, 28 to 117 days old, were collected from 23 dairy farms and transported in a lorry, allowing direct contact between the calves, to 8 calf rearing farms. The average transport time per calf was $4.5 \mathrm{~h}$, ranging from 0.3 to $12.8 \mathrm{~h}$. The calves were sampled by nasal swabbing for mycoplasmas first before loading and then immediately after transport. Thirteen of the calves were transferred to farm I. They were placed in individual pens in a separate room to themselves, and were sampled at intervals for a period of 4 weeks.
\end{abstract}

Ten of the 42 calves $(23.8 \%)$ originating from 5 of the source farms were found initially positive for M. dispar with titers $\geq 4 \log _{10}$ ccu; 3 of these 10 calves were delivered to farm I and 7 calves to 6 others of the 8 receiving farms. Three initially infected calved delivered to farms I continued to be positive throughout the follow-up period; among the 10 initially negative calves the frequency of detected infection, and the geometric mean titer (within parenthesis), developed so that on days $1,7,14$, and 28 the figures were: 2 (2.5), $8(4.3), 9(4.7)$, and 10 (5.5), respectively.

After transport 3 initially negative calves were found positive with low titers. Two of them were placed on farm I. In one of them positivity proved to be only transient; the case seems to represent a phenomenon of transfer of mycoplasmas without establishment of infection. In contrast, at least 4 (possibly 7) calves, negative both before and after transport - ascribed above to the group of 10 initially negative calves arriving on farm I - had in all likelihood caught the infection during the transport. Two of the 10 calves most likely caught the infection on the farm; for 3 calves the evidence was equivocal as to the 2 alternatives.

Seven of the 42 calves $(16.7 \%$ ) were found to be initially infected with M. bovirhinis, 2 of the 42 with Acholeplasma laidlawii. Among the 13 calves transported to an reared on farm I, 8 were found to be positive at least once for M. bovirhinis during the study. Colonisation by this mycoplasma was partly detected only intermittently and the detectable prevalence among the 13 calves at its highest was only $38.5 \%$.

Mycoplasma infections; mycoplasmosis in cattle; respiratory diseases of cattle; epidemiology; disease transmission; calf transport. 


\section{Introduction}

The results of an experimental study (Tanskanen $1987 \mathrm{~b}$ ) were indicative of a relatively high ability of Mycoplasma dispar infection to spread in conditions of close proximity between susceptible and infected calves. An exposure time of only a few hours seemed usually to be sufficient for transmission of infection when susceptible and infected calves were put together in the same pen. Separation of susceptibles from the source of infection even with a short distance tended to delay the transmission of infection. The prevalence of $\mathrm{M}$. dispar, as high as $97.0 \%$ (96 of 99) in the group of 1- to 2-months old calves on infected calf rearing farms, as demonstrated by the previous field study (Tanskanen 1987a), was also suggestive of a high efficiency of this species to spread under the rearing conditions described. The aim of the present study is to learn more about the pattern and rate of spread of M. dispar infection in natural settings of calf transportation and rearing.

\section{Materials and methods \\ Calves and their collection}

This survey was carried out, as regards its longitudinal main part, on a calf rearing farm (farm I) located in the Rautalampi district in southwest Savo and was geographically extended, as a study of conditions of origin of calves and of influence of common transport on them, into the area of this and neighbouring districts. The latter mentioned part of the study took place in connection with the collection of new calves for rearing on both farm I and 7 other farms. Farm I was specialized in rearing bull calves for beef. The total number of calves being reared on farm I at a time was close 100 . New calves were purchased in batches of 10-14 from dairy farms in the surrounding districts and delivered through organized distribution channels. New arrivals were placed in a separate room which was connected by a door with an adjacent larger room accommodating the older calves. The calves were reared for approximately 1 month in the smaller room and moved thereafter to the larger one. The room for arrivals was thoroughly cleaned and disinfected after moving on the preceding batch and then left vacant for at least 2 weeks before receiving new arrivals.

The collection of the 42 calves was carried out on 4 July 1983. Of the first 26 calves (nos. 1-26 in order of collection) collected from 13 dairy farms (A-M) and transported in a lorry allowing free mixing of calves, 13 calves (nos. 3-6, 9, 10, 12, 17, 19, 21, 23, 24 and 26) were delivered to farm I. These 13 calves originated from 9 dairy farms (B, C, E, F, H, I, J, L and M), 1-3 from each farm. The mean age of the 13 calves was 56.5 days, with a range of 28 to 87 days. Their transport time spent in the lorry before arrival at farm I was on average $2.4 \mathrm{~h}$, varying from 0.3 to $5.8 \mathrm{~h}$.

After the delivery of the batch of 13 calves to farm I, 16 additional calves (nos. 27-42) from 10 other dairy farms (N-W) were loaded into the lorry and, together with the 13 previously mentioned calves not delivered to farm I (i.e. nos. 1, 2, 7, 8, 11, 13-16, 18, 20, 22 and 25 ), delivered to 7 other calf rearing farms (II-VIII), 1-9 calves to each farm. The average transport time of all the 42 calves was $4.5 \mathrm{~h}$, ranging from 0.3 to $12.8 \mathrm{~h}$. The calves represented 3 breeds (25 Ayrshire, 13 Friesian, 1 Finncattle and 3 crossbreeds) and their mean age was 64.7 days, with the range of 28 to 117 days. The number of milking cows on the native dairy farms of the calves varied from 7 to 20 , with a mean of 12.5 cows. 
Accommodation of calves

The room ( $72 \mathrm{~m}^{3}$ in size) for new arrivals on farm I contained a double row of individual pens with raised floors, located on both sides of a central passage $1.3 \mathrm{~m}$ wide (Fig. 1). Individual pens (Alfa-Laval/Bambi/Hankkija) had 3 solid sides $1.3 \mathrm{~m}$ in height and a front side with equipment for feeding. Adjacent calves had the possibility to come into direct contact with each other both during feed intake and across the upper edges of the adjacent sides of the pens. Individual buckets were not used for feeding. Buckets were, however, throughly cleaned between feeding times. The room was ventilated in a primitive manner: outlet was in the roof in the centre part of the room and inlet was through the door from the larger animal room. Air space per a calf $\left(5.5 \mathrm{~m}^{3}\right)$ was relatively small according to the criteria given by Webster (1984). This together with an inefficient ventilation created a somewhat unsatisfactory air hygiene in the room. The relative humidity was usually around $70-80 \%$ but increased on moist days to $90 \%$ or over. The temperature in the room at the time of the studies varied from 18 to $25^{\circ} \mathrm{C}$.

\section{Sampling}

The nasal swab specimens were taken in a manner previously described (Tanskanen 1984). All the calves were sampled twice in connection with transport: first on their native dairy farms before loading and the second time after transport before transfer into the buildings at their farm of destination. The 13 calves transported to farm I were further sampled on days $1,7,14$ and 28 post arrival. The specimens (mycoplasma broths with swabs) were transported within 1 to 2 days to the laboratory and cultured either immediately of after a storage period of a few months at $-70^{\circ} \mathrm{C}$.
Culture and identification of mycoplasmas The medium used for the transport and culture of specimens was a modification of the glucose calf-serum medium described by Gourlay \& Leach (1970). The preparation of this medium as well as the methods of culturing and identification of mycoplasmas have been described previously (Tanskanen 1984).

\section{Results}

\section{Occurrence of M.dispar}

Table 1 shows that among the 42 calves studied in connection with the transport, 10

Table 1. The titers for Mycoplasma dispar and Mycoplasma bovirhinis in nasal swab specimens of calves found to be infected before or/and after the transport among 42 calves supplied by 23 dairy farms (A-W) and distributed in a lorry to 8 calf rearing farms (I-XIII).

\begin{tabular}{|c|c|c|c|c|}
\hline \multirow{2}{*}{$\begin{array}{l}\text { Calf } \\
\text { no }\end{array}$} & \multirow{2}{*}{$\begin{array}{l}\text { Dairy } \\
\text { farm }\end{array}$} & \multirow{2}{*}{$\begin{array}{c}\text { Calf } \\
\text { rearing } \\
\text { farm }\end{array}$} & \multicolumn{2}{|c|}{$\begin{array}{l}\text { Titer before (after) transport } \\
\left.\qquad \log _{10} \mathrm{ccu}\right)\end{array}$} \\
\hline & & & M. dispar & M. bovirhinis \\
\hline 5 & C & I & $-(-)$ & $4(-)^{*}$ \\
\hline 6 & C & I & $-(2)$ & $-(-)$ \\
\hline 15 & G & VIII & $5(6)$ & $4(-)$ \\
\hline 16 & G & II & $4(5)$ & $5(4)$ \\
\hline 17 & $\mathrm{H}$ & I & $-(-)$ & $5(3)$ \\
\hline 18 & I & VIII & $6(4)$ & $-(-)$ \\
\hline 19 & I & I & $5(3)^{*}$ & $2(-)$ \\
\hline 20 & I & VII & $4(4)$ & $-(-)$ \\
\hline 22 & $\mathrm{~K}$ & $\mathrm{~V}$ & $-(3)$ & $-(-)$ \\
\hline 23 & $\mathrm{~L}$ & I & $5(5)$ & $-(-)$ \\
\hline 24 & L & I & $5(4)$ & $-(-)$ \\
\hline 25 & L & VII & $5(5)$ & $-(-)$ \\
\hline 26 & M & I & $-(2)$ & $-(-)$ \\
\hline 35 & $\mathrm{~S}$ & VI & $5(6)$ & $-(-)$ \\
\hline 36 & $\mathrm{~T}$ & III & $5(6)$ & $2(3)$ \\
\hline 37 & $\mathrm{U}$ & III & $-(-)$ & $3(-)$ \\
\hline
\end{tabular}

The mean titer/S.D. of positive specimens 4.9/0.6 (4.2/1.4) 3.6/1.3 (3.3/0.6)

- negative specimen.

* The specimen was heavily contaminated with bacteria. 
(23.8\%) were found to be infected already on their native farms, all with nasal titers equal to or over $4 \log _{10} \mathrm{ccu}$, this continuing after transport. (The above mentioned calves will be referred to later in the text as "initially infected calves".) They originated from 5 to 23 dairy farms $(21.7 \%)$ supplying the 42 calves, and were distributed to 6 of the 8 calf rearing farms. Three of them (nos. 19, 23 and 24), originating from dairy herds I and $\mathrm{L}$, were brought to farm I. All calves, supplied from a dairy farm which proved to be infected ( 1 to 3 per farm), were found to be infected. The mean number (with S.D.) of milking cows on the infected farms was 14.8 (1.9) as compared to 11.8 (4.0) on noninfected farms (i.e. all calves sold were negative according to the result of nasal testing). The difference was not significant $(\mathrm{p}>.05$, Mann-Whitney-test). The latest purchases of cattle to the 5 infected dairy farms had occurred 3 to 20 years before.

As further shown in Table 1, three additional calves (nos. 6, 22 and 26) exhibited low titers for M. dispar immediately post transport, after having been negative before trans- port. The lengths of time spent by these calves in the lorry, together with initially infected calves, were $1.8,7.6$ and $0.3 \mathrm{~h}$, respectively. Two of these 3 calves were transported to farm I, the third to farm V. In all, one or more of calves recognized as infected after transport were placed on 7 of the 8 calf rearing farms.

Fig. 1 presents the results of nasal isolation of M. dispar from the 13 calves, both on arrival at farm $I$ and at intervals, during the first 4 weeks of rearing. The figure also indicates the positions of these 13 calves in the room. As shown, 5 (38.5\%), 11 (84.6\%), 12 $(92.3 \%)$, and $13(100 \%)$ of the calves were recognizably infected on days $1,7,14$, and 28 , respectively. The mean titers (S.D.) for M. dispar in positive calves were at these 4 sampling times 4.4 (1.8), 4.5 (1.4), 4.7 (1.2), and $5.2(1.0) \log _{10}$ ccu, respectively; if the 3 initially infected calves are excluded the figures will be $2.5(0.7), 4.3$ (1.3), 4.7 (1.2), and $5.5(0.7)$, respectively.

Of the 10 initially uninfected calves (i.e. negative when sampled on their native farms) transported to farm I, 8 were positive for
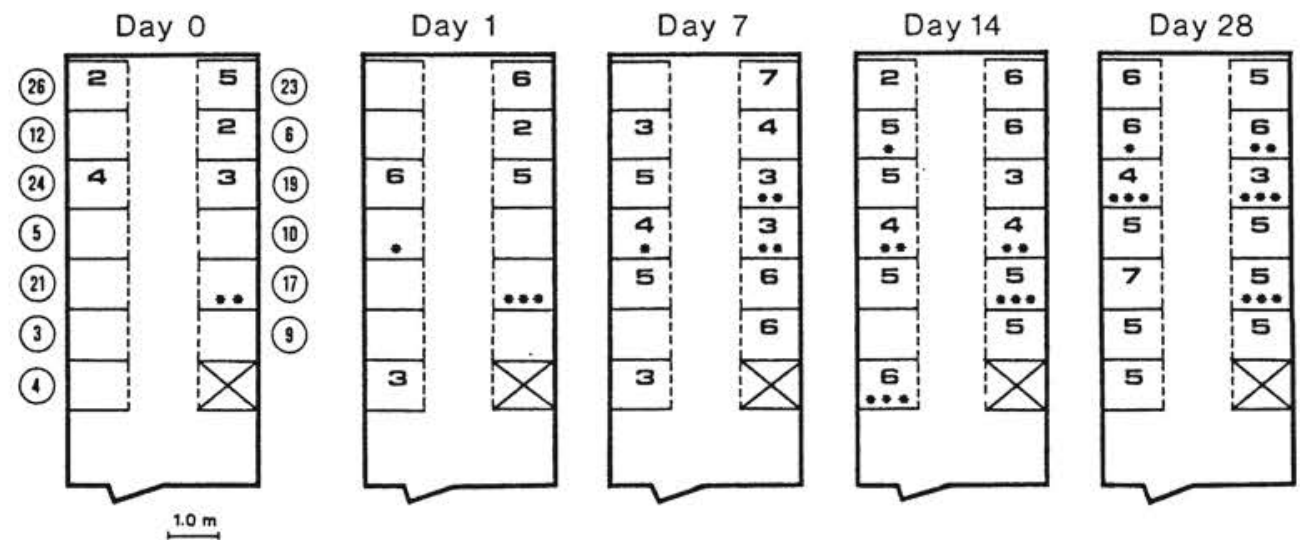

Figure 1. The layout of pens with the positions of 13 arrivals on farm I (circled numbers indicate the positions of the calves) and nasal titers for Mycoplasma dispar and Mycoplasma bovirhinis on arrival at farm (day 0 ) and on days $1,7,14$ and 28 post arrival. Nos. 2 to 7 within the pens indicate the titers for M. dispar in $\log _{10}$ ccu. Symbols of titer levels for M. bovirhinis: $(*)=1-2 ;(* *)=3-4 ;\left(^{* * *}\right)=\geq 5 \log _{10}$ ccu. 
$M$ dispar on day 7 , with titers ranging from 3 to $7 \log _{10} \mathrm{ccu} ; 3$ of them (nos. 9, 17 and 21 ) had titers $\geq 5 \log _{10}$ ccu, 4 calves (nos. 4 , $5,6,10$ and 12), evidencing slower development of colonisation, showed values of 3-4 $\log _{10}$ ccu. Among the 8 calves only nos. 4 and 6 were positive already on day 1 , the latter also on arrival at farm I. Calves 3 and 26 were exceptional: the former was found infected no earlier than on day 28 and the latter - during its stay on the farm I - on day 14 with a titer of $2 \log _{10} \mathrm{ccu}$. Calf no. 26 had shown a transient positivity (titer $2 \log _{10}$ ccu) on arrival at farm I.

Calves nos. 9, 17 and 21, exhibiting the most rapid development of colonisation to the level of high nasal titers, were not kept in pens adjacent to those of the initially infected calves (nos. 19, 23 and 24). Similarly, calf no. 4 , found to be infected already on day 1 , was distanced by 3 pens from the nearest initially infected calf. These spatial relations are an argument against the 4 calves having caught the infection on farm I through direct droplet contact from initially infected calves.

Calves nos. 3 and 26 , with relatively late nasal positivity associated with developing colonisation, probably did not acquire the infection until well settled on farm I. Calves nos. 6 and 26, with their low M. dispar titers post transport, seem each to represent one of two alternatives of further development; in the former case transferred organisms started a successful colonisation, in the latter the attempt to establish infection appears to have failed.

No clinical signs of respiratory tract disease were detected at the times of sampling among the 42 calves transported or among the 13 calves during the study period on farm I.

\section{Occurrence of other mycplasmas}

As Table 1 shows, $7(16.7 \%)$ of the $42 \mathrm{cal}-$ ves transported, originating from $6(26.1 \%)$ of 23 dairy farms, were found to be infected with $\mathrm{M}$. bovirhinis at the departure from their native dairy farms. Only 3 of these 7 calves continued to be positive when sampled anew after transport. This result suggests a relatively low reliability for nasal swabbing in the detection of M. bovirhinis infection in this survey. In contrast to the findings on M. dispar, no additional calves were found to be infected when sampled immediately after transport. Also, not all of the calves originating from the infected farms were found to be infected; for example, only 1 among each 3 calves, obtained from farms $\mathrm{C}$ and I, were found to be positive for M. bovirhinis when sampled on their native farms. Three calves (nos. 5, 17 and 19) found to be infected with $\mathrm{M}$. bovirhinis before transport were delivered to farm I. As shown in Fig. 1, $2(15.4 \%), 3(23.0 \%), 5(38.5 \%)$, and 5 $(38.5 \%)$ of the 13 calves purchased by farm I were found positive for $\mathrm{M}$. bovirhinis on sampling days $1,7,14$, and 28 , respectively. In contrast to the pattern for M. dispar, calves detected to be infected at one sampling were not consistently positive in later samplings. By the 4 th week, 8 (61.5\%) of the calves had been detected to be positive for M. bovirhinis at least once. First detections of the agent were made on days 7,14 , and 28 in 1,2 , and 2 calves, respectively.

Acholeplasma laidlawii was isolated from 2 calves (nos. 2 and 8), originating from 2 different dairy farms, at sampling prior to transport but only from one of them post transport. No isolations were made during the study period on farm I.

\section{Discussion}

The identification both of calves infected by M. dispar on their native dairy farms and of 
those uninfected seems to have been quite valic. All the infected calves had titers of 4 $\log _{10}$ ccu or higher at the first measurement, with a subsequent maintaining of the general level. The high titers among 1- to 3-month old calves in a herd endemically infected with M. dispar are expected because of relatively high transmissibility of the infection through contact (Tanskanen 1987b) and because of the typically long duration of highdegree colonisation of the respiratory tract of calves with this agent (Tanskanen 1984). In the light of the results referred to above the negative results also seem reliable. That an exceptional case like calf no. 6 , with its positivity both on arrival in farm I and on day 1 , and with an ensuing titer rise, may have become infected - untypically late - on its native farm is theoretically possible, but improbable. A similarly occurring rapid colonisation immediately after infection has been observed in experiments on natural transmission (Tanskanen 1987b).

Both the patterns of the appearance and further development of nasal M. dispar titers among, and the temporal order and spatial relations between, the 10 initially uninfected calves on farm I indicate that in all likelihood at least 5 of them (nos. 4, 6, 9, 17 and 21 ), or even 8 , caught the infection already in the transport lorry and at most 5 , or only 2 (nos. 3 and 26), later when being placed in the pens on farm I. This contention is specifically supported by the comparative data from the studies on natural transmission in an experimental setting; first detection of an established infection in susceptibles was made on average 4.5 days after exposure at close contact, with the range of 1 to 27 days, and the range of time for developing colonisations to reach the level of $5 \log _{10} \mathrm{ccu}$ in nasal titers was wide enough to cover the patterns exhibited by the 8 calves referred to above (Tanskanen 1987b). While circum- stantial evidence for 5 calves having caught the infection during the transportation is rather strong, in the case of 3 of 8 calves (nos. 5, 10 and 12) the combined data appear to the equivocal as to their becoming infected in the lorry or on the farm.

Three of 32 initially uninfected calves turned positive with titers of 2 to $3 \log _{10} \mathrm{ccu}$ during the transport. Two of these calves were placed on farm I. These titers obviously signify only transfer of the organisms and not their multiplication in the calves tested. They may, of course, represent the dose of which a part actually will infect or has infected (colonised) the receiver, but, as observed in the experimental studies (Tanskanen 1987b), they will not necessarily be a sign and/or a cause of subsequent infection. In this study calf no. 26, brought to farm I was in all likelihood a case of detected transfer of M. dispar without a production of infection. On the other side, both the present results and the earlier data from studies in an experimental setting (Tanskanen 1987b), clearly and not unexpectedly, have demonstrated that a recently established infection may stay latent - for detection by nasal swabbing - at least for a few days. In the experimental study referred to above, an exposure of $4 \mathrm{~h}$ at direct contact with infected calves induced an infection in 3 of 4 susceptibles which was detectable only after a latent period. In the present context, the same was specifically revealed by the test negativity post transport of the 4 calves (nos. 4, 9, 17 and 21) which in all likelihood had become infected during transport.

The described process of calf collection and delivery to rearing farms is practised quite widely in this country. It appears to spread effectively M. dispar infection from the relatively few infected dairy farms to the new batches of calves on the rearing farms; 12 calves, demonstrated to be positive for 
M. dispar post transport among the 43 calves transported, were distributed to 7 of the 8 farms of destination. Calves that caught the infection in the lorry, but remained negative post transport and on day 1 on the farm, seem to have added considerably to the final number of calves carrying the infection. In the described setting, this makes it well probable that each of the 8 calf receiving farms also received one or more M. dispar strains. Earlier Hamdy \& Trapp (1967) have reported on the spread of mycoplasma infection in connection with calf transport.

As already stated, the relatively effective spreading of M. dispar observed in this study is clearly in agreement with the results of the earlier transmission study (Tanskanen 1987b); the same applies also to the high prevalence of $\mathrm{M}$. dispar infection among 1to 2-month old calves on calf rearing farms discovered in the earlier field study (Tanskanen 1987a). The seroconversion for M.dispar of all calves (29 of 161), which were negative on their arrival in 5 feedlots in Ontario, within approximately 28 days of rearing was reported by Rosendal \& Martin (1986). The result is indicative of the high transmissibility of $\mathrm{M}$. dispar under the conditions described.

There are only a few reports on the prevalence of M. dispar on dairy farms. Surprisingly, in the study of Springer et al. (1982) all 20 relatively large farms examined by nasal swabbing of 6 to 10 calves per farm were negative for $\mathrm{M}$. dispar. The prevalence of about $20 \%$ ( 5 of 23 ) in this study for infected dairy farms among those delivering calves to rearing farms is conspicuously lower than the prevalence of nearly $100 \%(23$ of 24) for calf rearing farms in this country (Tanskanen 1987a). Although only the calves sold and transported in connection with the sale were examined from each dairy farm in this survey, it is unlikely that the farms delivering 1 to $4 \mathrm{M}$. dispar negative calves of the most susceptible age would have had a latent reservoir of the agent. This conclusion is supported by the earlier data on durability and easy detectability of the infection referred to above. The presence of infection in all the calves delivered from each infected dairy farm in this study, as well as the result of a $100 \%$ prevalence of M. dispar at the last sampling on farm I, both lend additional support to the concept of high level endemicity of M. dispar infection among young calves of infected farms.

The results recorded accounted for a higher transmissibility for M. dispar than for M. bovirhinis. To a certain extent the difference, however, may be only apparent because of the lower and less reliable detectability of M. bovirhinis, a conclusion supported by the variability among consecutive specimens recognised in the present and earlier study (Tanskanen 1984). The prevalence figures recorded correspond roughly to those reported previously by other workers (Dawson et al., 1966, Jurmanova et al. 1975). The great variability in M. bovirhinis titers, even between positivity and negativity in consecutive specimens of one and the same animal has not been reported in any of the studies carried out by others.

\section{Acknowledgements}

This study received financial support from The Research Council for Medical Sciences of the Academy of Finland and The Finnish Veterinary Science Foundation.

\section{References}

Dawson PS, Stuart P, Darbyshire JH, Parker $W H, M c C r e a C T$ : Respiratory disease in a group of intensively reared calves. Vet. Rec. 1966, 78, 543-546.

Gourlay RN, Leach RH: A new mycoplasma species isolated from pneumonic lungs of calves 
(Mycoplasma dispar sp. nov.). J. med. Microbiol. 1970, 3, 111-123.

Hamdy $A H$, Trapp $A L$ : Investigation of nasal microflora of feedlot calves before and after weaning. Amer. J. vet. Res. 1967, 28, 10191025.

Jurmanova $K$, Kuzel M, Mensik J: The role of mycoplasmas in the development of the chronic respiratory syndrome in calves and young cattle. III. The incidence of mycoplasmas in the upper respiratory tract of calves exposed to natural infection in a large-capacity calf house with continuous operation. Docum. vet. Brno, 1975, 8, 403-409.

Rosendal S, Martin SW: The association between serological evidence of mycoplasma infection and respiratory disease in feedlot calves. Canad. J. vet. Res. 1986, 50, 179-183.

Springer WT, Fulton RW, Hagstand HV, Nicholson SS, Garton JD: Prevalence of Mycoplasma and Chlamydia in the nasal flora of dairy calves. Vet. Microbiol. 1982, 7, 351-357.

Tanskanen $R$ : Colonisation pattern of the respiratory tract of calves by Mycoplasma dispar. Acta vet. scand. 1984, 25, 577-592.

Tanskanen $R$ : The prevalence and level of colonisation by Mycoplasma dispar and other mycoplasmas on calf rearing farms. Acta vet. scand. 1987a, 28, 209-226.

Tanskanen $R$ : Transmissibility of Mycoplasma dispar under experimentel conditions. Acta vet. scand. 1987b, 28, 227-240.

Webster J: Calf Husbandry, Health and Welfare. Granada Publishing Ltd., London 1984, p. 95.

\section{Sammendrag}

Spridning av Mycoplasma dispar bland uppsamlade mellankalvar.

Fyrtiotvå kalvar i åldern 28 till 117 dagar samlades från 23 mjölkkobesättningar och fördes i en transportvagn som möjliggjorde direkt kontakt mellan djuren till 8 kalvuppfödningsbesättningar.
Transporttiden var i medeltal 4.5 timmar per kalv och varierade mellan 0.3 och 12.8 timmar. Provtagning med avseende på mykoplasma från nässlemhinnan togs först före lastningen och därefter genast efter transporten. Tretton kalvar flyttades till gård I. Kalvarna placerades i enskilda boxar i ett eget rum och undersöktes med jämna mellanrum under 4 veckors tid.

Tio av de 42 kalvarna (23.8\%) som kom från 5 ursprungbesättningar var från børjan positiva för M. dispar med tittrar $\geq 4 \log _{10}$ ccu; 3 av dessa 10 kalvar fördes till gård I och 7 till 6 andra bland emottagande gårdar. De 3 kalvar som var infekterade från början och som fördes till gård I förblev positiva under uppfödningsperioden; bland 10 från början negativa kalvar var frekvensen av påvisad infektion och den geometriska medeltitern (inom parentes) på dagarna $1,7,14$ och 28 följande: 2 (2.5), 8 (4.3), 9 (4.7) och $10(5.5)$.

Efter transporten blev 3 från början negativa kalvar positiva med låga titrar. Två av dessa placerades på gård I. Hos en av dessa kalvar visade sig posiviteten vara övergående; fallet tycks representere en slags spridning av mykoplasmer utan etablering av infektion. I motsats till detta hade åtminstone 4 (möjligen 7) kalvar, negativa både före och efter transporten - de beskrivs ovan som tillhörande gruppen från början negativa kalvar som anlände till gård I - med all sannolikhet smittats under transporten. Två av de 10 kalvarna smittades sannolikt på gården, för de övriga 3 kalvarna var båda alternativen bevisligen möjliga.

Sju av de 42 kalvarna (16.7\%) var från början infekterade med $\mathrm{M}$. bovirhinis och 2 kalvar av 42 med Acholeplasma laidlawii. Bland de 13 kalvarna som transporterades till och födds upp på gård I lyckades isoleringen av M. bovirhinis hos 8 kalvar åtminstone en gång under undersökningen. Delvis påvisades kolonisation med denna mykoplasma endast periodvis. Den påvisade maximal prevalensen bland de 13 kalvarna var endast $38.5 \%$.

(Received December 23, 1986).

Reprints may be requested from: Raili Tanskanen, Department of Microbiology and Epizootology, College of Veterinary Medicine, P. O. Box 6, SF-00551 Helsinki 55, Finland. 